\title{
Testing for Price Co-Integration between Producers and Retailers: Evidence from Ethiopian Milk Market
}

\author{
Habtamu Regassa Lemma, Rajwinder Singh \\ School of Management Studies, Punjabi University, Patiala, India \\ Email: habtamuregassa@rocketmail.com, rajwindergheer@gmail.com
}

Received 18 January 2015; accepted 2 February 2015; published 5 February 2015

Copyright (C) 2015 by authors and Scientific Research Publishing Inc.

This work is licensed under the Creative Commons Attribution International License (CC BY). http://creativecommons.org/licenses/by/4.0/

(c) (i) Open Access

\section{Abstract}

The purpose of this paper is to test how producers' and retailers' prices are horizontally integrated, and to show the direction of causality that exists between producers' price and retails' price in Ethiopian milk market. The study was conducted making use of secondary data extracted from Ethiopian central statistics agency. The data was time series having 120 observations of monthly recorded price series of producers and retailers, for the period from January, 2004 to December 2013. For this purpose, descriptive statistics and time series econometrics approach (Johansen's test for co-integration and Vector Error Correction Model) were employed. The study shows that there is strong long run co-integration between producers' price and retailers' price. The policy implication is that the markets are co-integrated in terms of price transmission. However, the causality test shows that retailers are dominant over price determination. In other words, producer's price is caused by retailers' price; but producers' price doesn't cause retailers' price. This shows that the market structure is in favor of retailers/traders, which can adversely affect the welfare of producers and consumers.

\section{Keywords}

Milk Price, Co-Integration, Vector Error Correction Model, Producers, Retailers

\section{Introduction}

The achievements of market reforms in the third world countries rely to a large extent on the strength of price signals transmitted within various levels of market. With this regard the coordination between producers, wholesalers and retail prices keep up to be of a widely regarded economic interest. The relationship between farm 
and retail prices provides insights into marketing efficiency as well as consumer and producer welfare. Regarding to price theory, flexible prices are responsible for efficient resource allocation and price transmission integrates markets spatially [1].

In bargaining of prices, the point of agreement amongst processors is that well established relationship with retail buyers is essential. Retailers are sometimes considered as business people who bargain hard but realistically; on the other hand, some people think that retailers are dishonest towards buyers and include extra profit margins or do not let them share in rebates. Consumer's institutions suggest that consumers are not benefited by price advantages of cheap and often subsidized imported dairy products. Consumer institutions indicate that many retailers would keep on their shelves dairy products of relative small processors at low prices as a way of "encouraging" the rest to "toe the line". In some instances, retailers knowingly stock fresh milk from suppliers.

According to a study done by USAID, in Ethiopia, most dairy products are distributed through supermarkets. Currently in Addis Ababa there are 25 bigger supermarkets owned by 15 companies and out of which 12 are owned by Ethiopian and the other 3 by foreigners. Moreover other supermarkets also exist in major towns of the country which distribute milk and milk products processed by milk processing companies based in Addis Ababa [2]. Retailers are the primary outlets for dairy products to the consumer. This indicates that, market domination of retailers and processors intends to reduce earnings and profitability of the farmers/producers from milk.

\section{Objectives of the Study}

The general objective of the study was to investigate milk price co-integration between producers and retailers in Ethiopia. More specifically, the study was undertaken;

- To assess the short-term and long-term association between producers' price and retailers' price

- To show the direction of causality that exists between producers' price and retails' price

\section{Literature Review}

Some of the main previous research study findings are highlighted in this research paper. These prominent research papers are further classified as per their focus area:

Tesfu [3] investigated the empirical evidence on the price transmission among the producer, wholesale, and retail markets, using monthly data from 1993 to 2010. The analysis was based on the Granger causality and the Johansen co-integration tests and on the asymmetry tests (Houck approach and error correction model approach). The causality test results show that the changes in producer prices cause changes in the wholesale and retail prices; there is a feedback from the retail to producer prices. Moreover, the direction of causality between the wholesale and retail prices flows in both directions. The long-run elasticity of price transmission is, as expected, greater than the short-run elasticity. The results indicate that there is co-integration between not only the wholesale and producer prices but also between the retail and producer prices. The results of an asymmetric error correction models also suggest that the price transmission in the Slovakian liquid milk market is asymmetric both in the short- and long-runs.

Baghestany \& Sherafatm [4] examined the price transmission between wholesale price and consumer price for milk in Iran. Price transmission could be of necessity if any price variation in different farm levels get path through retail level asymmetrically. Results of Granger causality show that there is one side relation from whole sale price to retail price in the milk market. Results also show that in the recession regime wholesale price has an influence on consumer price.

Barahona et al. [5] analyzed asymmetric price transmission in the artisan dairy industry of Honduras using Johansen multivariate approach and the Engle-Granger two step analyses. The study revealed that fluid milk prices have a strong co-integration with prices of fresh and dry cheese. In addition, dairy products that exhibit high market competition showed negative asymmetric price transmission whereas those that exhibit low market competition showed positive asymmetric price transmission.

Octavio, F., Josef, B., \& Jesus, C [6] studied the Role of Asymmetries in the Price Transmission Mechanism for Milk Products in Austria. The study was conducted based on time series econometric approach using vector error correction (VEC) models. The result shows that asymmetries play an important role in the pass through of prices for milk products in Austria. The study also revealed that milk, and milk products tend to remain in positive margins and measured as deviations from the long-run equilibrium for the retailers' side.

Katrakilidis C [7] examined testing for market integration and the law of one price: An application to selected 
European milk markets. The study used multivariate co-integration and Vector Error Correction model (VECM). The results revealed that the existence of a single common trend which leads the set of price series. The finding suggests that the examined EU milk markets are strongly interdependent and the degree of market integration may be considered "perfect". The result also show that German and Denmark milk markets dominate in Europe and drive the milk prices of the other markets.

Rumankova L [8] conducted research on Examination of market structure in selected livestock agri-food chains in the Czech Republic. The study used Descriptive analysis and Multivariate time series (VAR and VECM models). The result shows that the analyzed agri-food chains can be considered as markets with imperfect competition, in the form of either oligopsony or oligopoly. The nature of the market structure shows some differences among the analyzed agri-food chains. In almost all cases, it can be assumed that wholesalers have a stronger position than farmers. Thus, most of the analyzed agri-food chains can be measured based on demanddriven.

Bakucs, Z. Falkowski, J. Ferto, I [9] evaluated price transmission based on Time series methodology using co-integration and VECM. The objective of the study was to investigate the price transmission mechanism in two countries from the region, namely Poland and Hungary. The result shows that Polish milk prices, as opposed to Hungarian ones, are characterized by short- and long-term asymmetries.

Chalajour and Feizabadi [10] also conducted research regarding price transmission analysis in the Iranian rice market. The purpose of the study was to test whether changes in the marketing margin between the farm and the retail prices can result in an asymmetric relationship between the farm and the retail prices in the rice market of Iran. The study shows that when the marketing margin is lower than the threshold value, the market system operates freely and there is feedback between the farm and retail prices. The study also revealed that Changes in the marketing margin will lead to the asymmetric price transmission between the farm and retail prices.

Asche, Jaffry \& Hartmann [11] studied Vertical and horizontal price linkages for salmon by using Time series econometric model. The study suggested that the Relationships between prices are of interest when testing for market integration as well as analyses of supply chains. A feature that has received little attention is that if two supply chains are linked by market integration at some stage, then the whole supply chains will be linked. The result also shows the availability of high degree of price transmission in supply chain management, and market integration.

Bor, Ismihan \& Bayaner [12] conducted research on farm-retail price transmission in the Turkish fluid milk market using Time series econometric approach (co-integration and asymmetric error correction model). The results suggest that there is a positive price asymmetry in the farm-retail price transmission in the Turkish milk market. That is, the retail prices tend to adjust more quickly to the input price increases than to their decreases which yield welfare losses to the consumers. The co-integration results also show that there is a significant market power in the Turkish fluid milk market.

\section{Research Methodology}

The methodology of the paper is both descriptive and quantitative in nature. The study was conducted making use of secondary data extracted from Ethiopian Central Statistical Agency. The data was time series having 120 observations of monthly recorded price series of producers and retailers, for the period from January, 2004 to December, 2013. The data was analyzed using descriptive statistics and time series econometrics approach via STATA software. The descriptive analysis deals with comparison of trend of price movements for both producers and retailers. This involves graphical presentation of the price series and comparison of price variations using F-statistic. With regard to the quantitative analysis, test of co-integration and Vector Error Correction Model (VECM) were used to show how price in both stage of supply (producers and retailers) are integrated.

\subsection{Test of Stationarity of the Two Price Series}

This is done to test for presence of non-stationarity co-variance as well as to determine order of integration of each variable. It is often expected that price levels exhibit non-stationary covariance, which may lead to autocorrelation problems in the price response functions. This may result in spurious regression when we estimate the relationship between the price series. Hence, the unit root test was undertaken to know if the monthly market prices are stationary or not, using Augmented Dickey Fuller test [13].

If we express the two prices (producers' price and retails' price) as an autoregressive process of order one as: 


$$
P_{t}^{p}=\alpha+\beta P_{t-1}^{p}+\varepsilon_{t} \text { and } P_{t}^{r}=\rho+\theta P_{t-1}^{r}+v_{t}
$$

where: $P_{t}^{p}=$ producers' price

$P_{t}^{r}=$ retailers' price

$\alpha, \beta, \rho$, and $\theta$ are constants

$\varepsilon_{t}$ and $v_{t}$ are error terms

The Augmented Dickey-Fuller test involves regressing the first difference of these price series on own lagged values and testing for stationarity or non-stationarity, as shown below.

where:

$$
\begin{aligned}
& \Delta P_{t}^{p}=\delta+\gamma P_{t-1}^{p}+\sum_{t-1}^{t} \Delta P_{t-1}^{p}+\varepsilon_{t} \\
& \Delta P_{t}^{r}=\sigma+\varphi P_{t-1}^{r}+\sum_{t-1}^{t} \Delta P_{t-1}^{r}+v_{t}
\end{aligned}
$$

$$
\gamma=\beta-1 \text { and } \varphi=\theta-1
$$

$\Delta P_{t}^{p}=$ first difference or change in price of producers

$\Delta P_{t}^{r}=$ first difference or change in price of retailers

The set of hypotheses is defined as:

Ho: $\gamma=0$ for producers' price (i.e. producers price series have a unit root or are non-stationary) and

Ho: $\varphi=0$ for retails' price (i.e. retails price series have a unit root or are non-stationary)

If the variables are non-stationary (or if we accept the null hypothesis), the co-integration test will follow.

\subsection{Test of Co-Integration of the Two Price Series Using Johansen and Juselius' (1990) Approach}

After the stationarity test, we need to examine the existence of co-integration between the two variables. In this case, we search for the existence of the number of co-integrated vectors, r, within Johansen and Juselius' [14] framework. Using their technique, we implement a k-dimensional VAR of the following form:

$$
P_{t}=\mu+\sum_{j=1}^{k} \Pi_{i} P_{t-1}+e_{t}
$$

where: $P_{t}=$ is a $(2 \times 1)$ vector matrix of the producers and retail prices

$e_{t}=$ are Gaussian residuals.

$j=$ no. of lags in observation

The VAR in Equation (3) can be re-parameterized into a VECM form as:

$$
\Delta P_{t}=c+\Pi P_{t-1}+\sum_{j=1}^{k-1} B_{j} \Delta P_{t-j}+\varepsilon_{t}
$$

where: $\Pi$ is a $(2 \times 2)$ matrix of long-run and adjustment parameters, $B_{j}$ is a $(2 \times 2)$ matrix of the short-run parameters, $\varepsilon_{t}$ is the vector of residuals and $\mathrm{j}$ is the number of lags.

Following Johansen's procedure, the trace and maximum eigenvalue statistics are used to determine the rank of $\Pi$ and to reach a conclusion on the number of co-integrating equations, r.

\subsection{Causality Analysis between Producers' and Retailers' Price Series}

In the third stage of our approach, we have to define the direction of causality between the two variables. Therefore, we implement a complete dynamic Granger-Engle VECM test of the following form as indicated in Reziti and Panagopoulos, [15]:

$$
\begin{aligned}
& \Delta P_{t}^{r}=\mu_{1}+\sum_{i=1}^{n 1} \beta_{b} \Delta P_{t-i}^{r}+\sum_{i=1}^{n 2} \beta_{c} \Delta P_{t-i}^{p}+\Pi_{1} Z_{t 1-1}+e_{t 1} \\
& \Delta P_{t}^{p}=\mu_{2}+\sum_{i=1}^{n 1} \beta_{b} \Delta P_{t-i}^{r}+\sum_{i=1}^{n 2} \beta_{c} \Delta P_{t-i}^{p}+\Pi_{2} Z_{t 2-1}+e_{t 2}
\end{aligned}
$$

where $Z_{t 1-1}$ and $\Pi_{1} Z_{t 2-1}$ are adjustment or error correction terms whereas $\Pi_{1}$ and $\Pi_{2}$ are their respective coefficients and the $\beta$ are short-run coefficients. 
The set of hypotheses and options which are now available are as follows:

a) $\Pi_{1} \neq 0$ and $\Pi_{2} \neq 0$ (a feedback long-run relationship between the two variables)

b) $\Pi_{1}=0$ and $\Pi_{2} \neq 0$ (producers' price causes retails' price in the long-run)

c) $\Pi_{1} \neq 0$ and $\Pi_{2}=0$ (retails' price causes producers' price in the long-run)

\section{Result and Discussion}

\subsection{Descriptive Analysis}

In this section, comparative analysis of variation of the two price series is reported. The trends of producers' price and retailers' price is presented using Figure 1. Generally, the visual presentation of Figure 1 indicates that the two price series are moving together which can be a sign that there is association between producers' price and retailers' price, for the period between 2004 and 2013. This situation is also revealed by the trends of the percentage change in the two price series as indicated by Figure 2.

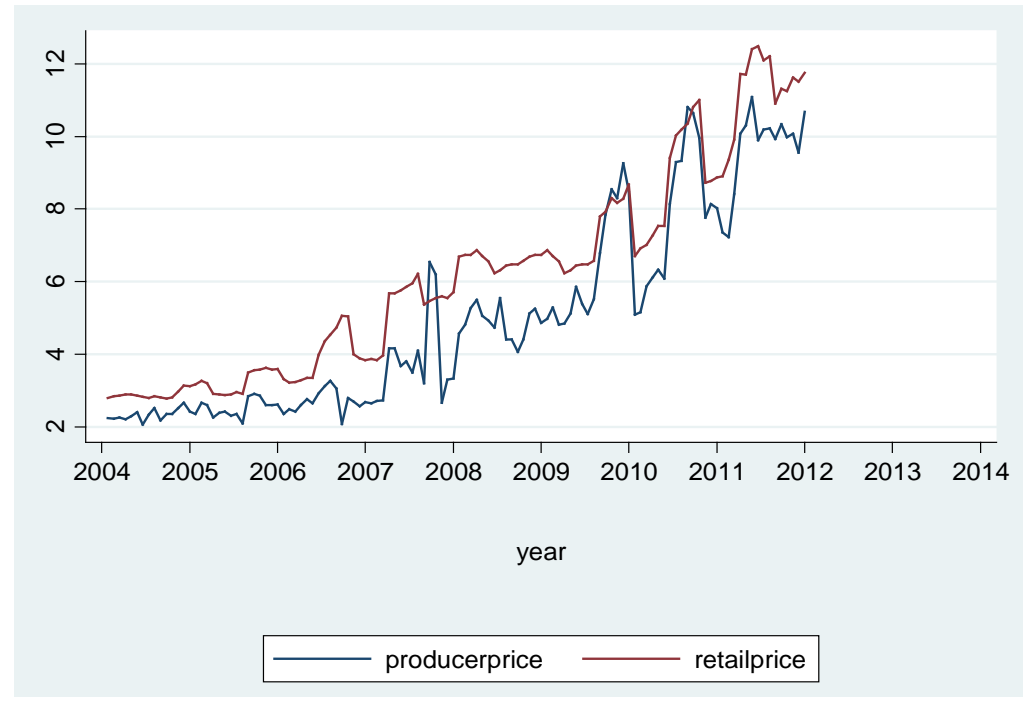

Figure 1. Trends of producers' and retails' price for the period between 2004 and 2013.

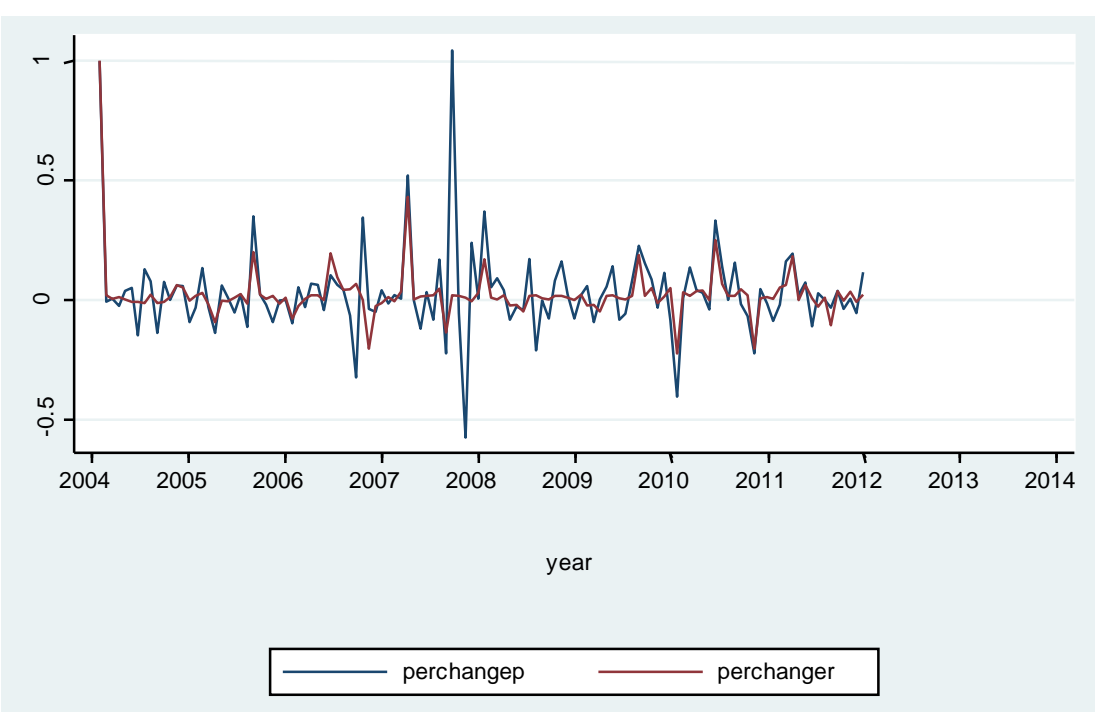

Figure 2. Trends of percentage change in producers' price and retails' price for the period between 2004 and 201. 
The overall trends of the variation in the two price series were found to be the same as indicated by the F-statistics shown in Table 1. The F-statistics was used to compare the variation of the two price series. Table 1 shows that standard deviations of producers' price and retailers' price are 2.76 and 2.84 , whereas standard errors of the two price series are 0.252 and 0.59 respectively. As indicated in the table, the value of the F-statistic is 0.9447 which is less than 1.26 (above which we reject the null hypothesis at $10 \%$ level of significance). This is to mean that we don't have any evidence to reject the null hypothesis that the extents of variations of the two price series are the same, even at $10 \%$ level of significance. The implication is that the extents of variations in the two prices are the same which is another indication that the two prices are moving together.

\subsection{Time Series Econometrics Analysis}

This section involves three steps/points of analysis including test of stationarity, test of co-integration, and test of causality

\subsubsection{Test of Stationarity (Unit Root Test)}

This test was undertaken to know if the variables have unit roots or not (if they are stationary or not), as well as to determine their order of integration, individually. As indicated in Table 2, producers' price and retails' price were found to be stationary in level. MacKinnon approximate P-values for $\mathrm{Z}(\mathrm{t})$ of producers' price and retails price are 0.0046 and 0.0525 , respectively; and their respective P-values of lagged prices are 0.000 and 0.001 . This shows that the prices are integrated of order zero as indicated by P-values. This implies that there is possibility of long-run relationship between the two price series, as they are expected to have common stochastic trend overtime.

\subsubsection{Test of Co-Integration between the Two Price Series}

To test for co-integration or fit co-integrating VECMs, we must first specify how many lags to include. Nielsen (2001) has shown that the methods implemented in lag-order selection statistics for VARs and VECMs can be used to determine the lag order for a VAR model with (1) variables. Accordingly, the lag-order selection statistics (LR, FPE, AIC, HQIC and SBIC) were computed. All these statistics show the same result that three lags

Table 1. Variance ratio test of the two price series.

\begin{tabular}{cccc}
\hline Variables & Observations & Standard Error & St. Deviation \\
\hline Producers price & 120 & 0.2520926 & 2.761536 \\
Retails price & 120 & 0.2593678 & 2.841232 \\
Combined & 240 & 0.1841997 & 2.85361 \\
Degree of freedom $=119$, & $\mathrm{F}=0.9447$ & &
\end{tabular}

Table 2. Augmented dickey fuller test for unit root (with trend) of producers' price and retails’ price.

\begin{tabular}{ccc}
\hline Stage of supply & Producers & Retailers \\
\hline Intercept & 0.1637712 & 2649805 \\
P-value & $(0.27)$ & $-0.024)$ \\
Price $t-1$ & -0.2707294 & $(0.001)$ \\
P-value & $(0.000)$ & 0.107915 \\
First diff of price & 0.1122096 & $(0.247)$ \\
P-value & $(0.231)$ & 0.0144725 \\
Trend & 0.020669 & $(0.001)$ \\
P-value & $(0.000)$ & 1 \\
L & 1 & 0.0525 \\
\hline
\end{tabular}


should be used in the estimation of the co-integration equation.

Once the number of lags was determined, the Johansen and Juselius' framework was implemented to determine the number of co-integration equations. The estimation result is presented in Table 3. This estimation was carried out to determine the rank of the co-integration matrix. As indicated in the table, we reject the hypothesis that there is no integration between producers' price and retails' price (i.e. $\mathrm{r}=0$ ). Because both the trace and the max statistics are greater than their respective $5 \%$ critical values when $r=0$. That is, $36.3710>18.17$ and $26.5210>16.87$. And also we have strongly enough evidence to reject the hypothesis that the number of co-integrating equations are not more than one since both the statistical values are greater than their respective 5\% critical values when $r \leq 1$ (i.e. $9.8500<3.74$ and $9.8500<3.74$ ). This co-integration test shows that there are two ways of long run associations between the prices. In other word, there is strong long run co-integration between producers' price and retails' price.

\subsubsection{Causality Analysis between Producers' and Retailers' Price Series}

By now, we have assured that there is co-integration between the two price series, and we have identified that there is no more than one co-integrating equation. Given this, we need to test which price causes the other. This was analyzed using Engel Granger-Vector Error Correction Model, as applied by Reziti and Panagopoulos [13]. The estimation result is presented in Table 4. Result of estimation of the model, once again, shows that there is only one co-integrating equation. Overall, the output indicates that the model fits well as indicated by the Rsquared and Chi-square results, at the footer of the table. We can see also that the estimates have the correct signs and imply rapid adjustment toward equilibrium.

The negative sign of the estimate of the coefficient of adjustment parameter on producers price (adjustment $\mathrm{p}_{\mathrm{p}}$ shows that when the average price of producer is too high, it quickly falls back toward the equilibrium level. Similarly, the positive sign of the estimated coefficient of adjustment parameter on retails price (adjustment $\mathrm{r}_{\mathrm{r}}$ implies that when the average price of the producers are high, the retailers average price will quickly adjusts by rising toward the equilibrium level.

Table 4 shows that, in our estimation of the VECM, there are two types of parameters of interest; including the adjustment and the short-run coefficients. The adjustment parameter on producers' price (i.e. adjustment $\mathrm{p}_{\mathrm{p}}$ ) has coefficient of -0.3738948 and P-value of 0.0000 implying that it is significant at $1 \%$ level of significance.

Table 3. Johansen's tests for co-integration of the price series (producer price \& retail price).

\begin{tabular}{|c|c|c|c|c|c|}
\hline \multirow{2}{*}{ Rank } & \multirow{2}{*}{ Eigen value } & \multicolumn{2}{|c|}{ Trace } & \multicolumn{2}{|c|}{ Max } \\
\hline & & Statistics & $5 \%$ critical value & Statistics & $5 \%$ critical value \\
\hline $\mathrm{r}=0$ & ----- & 36.3710 & 18.17 & 26.5210 & 16.87 \\
\hline $\mathrm{r} \leq 1$ & 0.19978 & 9.8500 & 3.74 & 9.8500 & 3.74 \\
\hline $\mathrm{r} \leq 2$ & 0.07944 & ---------- & -------- & ------- & ------- \\
\hline \multicolumn{6}{|c|}{ Number of obs $=119$ Lags $=1$} \\
\hline
\end{tabular}

Table 4. Vector error correction model (VECM).

\begin{tabular}{|c|c|c|c|c|}
\hline Dependent variable & Independent variables & Coefficient & Standard error & P-value \\
\hline & Adjustment $_{\mathrm{p}}$ & -0.3738948 & 0.0983138 & 0.000 \\
\hline \multirow[t]{3}{*}{$\Delta$ Pproducers } & Trend & 0.000069 & 0.0020562 & 0.973 \\
\hline & Constant $_{p}$ & -0.0012291 & 0.1405618 & 0.993 \\
\hline & Adjustment $_{\mathrm{r}}$ & 0.0247243 & 0.0639977 & 0.699 \\
\hline \multirow[t]{4}{*}{$\Delta$ Pretails } & Trend & 0.0010429 & 0.0013385 & 0.436 \\
\hline & Constant $_{\mathrm{r}}$ & 0.0172156 & 0.0914992 & 0.851 \\
\hline & \multicolumn{4}{|c|}{ No. of obs $=119$} \\
\hline & \multicolumn{2}{|c|}{ R-sq } & chi2 & $\mathrm{P}>$ chi2 \\
\hline Pproducers & \multicolumn{2}{|c|}{0.1203} & 15.86640 & 0.0012 \\
\hline Pretails & \multicolumn{2}{|c|}{0.0287} & 3.424623 & 0.3307 \\
\hline
\end{tabular}


On the other hand, the adjustment parameter on retail price (i.e. adjustment $\mathrm{r}_{\mathrm{r}}$ ) has coefficient of 0.0247243 and P-value of 0.699 , implying that it is not significant even at $10 \%$ level of significance. This reveals that there is only one way of causality. In other word; the causality test shows that retailers are dominant over price determination. That means producer's price is determined by retailers price or retailers price causes producer's price. But, producer's price does not cause retailers price.

Coefficient of the adjustment parameter when producers’ price becomes dependent variable, i.e. -0.3738948 shows the speed of adjustment of producers' price when there is change in retailers' price. It shows that for $100 \%$ change in price of retailers, the producers' price changes by about $37 \%$ in a month. This implies it takes more than two months for the producers' price to fully adjust if there is no additional shock in retail price. On the other hand, coefficient of the adjustment parameter when retailers' price is independent variable, i.e. 0.0247243 shows that for $100 \%$ change in price of producers, retailers' price changes by about $2.4 \%$ which is very insignificant, revealing that producers’ price does not significantly causes retailers’ price.

\section{Conclusion}

This study, by taking average prices of producers and retailers from nine (9) different regions in Ethiopia, undertakes the milk price co-integration analysis. The methodology of the paper is both descriptive and quantitative in nature. The descriptive analysis indicates that the two price series are moving together which can be a sign that there is an association between producers' price and retailers' price, for the period between 2004 and 2013. This situation is also revealed by the trends of the percentage change in the two price series. Secondly, result of the F-statistics shows that the extents of variations in the two prices are the same which is another indication that the two prices are associated. With regard to the quantitative analysis, the two prices were found to be associated which indicated the possibility of co-integration between them. This is also affirmed by the Johansen's test of co-integration implying that there is possibility of long-run relationship between the two price series, as they are expected to have common stochastic trend overtime. The policy implication is that the markets are co-integrated in terms of price transmission. However, the negative sign of the estimate of the coefficient of adjustment parameter on producers price (adjustment $\mathrm{p}_{\mathrm{p}}$ ) shows that when the average price of producer is too high, it quickly falls back toward the equilibrium level. Similarly, the positive sign of the estimated coefficient of adjustment parameter on retails’ price (adjustment ${ }_{\mathrm{r}}$ ) implies that when the average price of the producers are high, the retailers' average price will quickly adjust by rising toward the equilibrium level. This shows the market structure is in favor of retailers/traders, which can adversely affect the welfare of producers and consumers. Thus, the concerned authorities and other stakeholders will have to take necessary action to improve market coordination among farmers, distributors, retailers and customers. In this manner, the production capacity as well as market sustainability of farmers and customers can be assured as well.

\section{Acknowledgements}

The authors would like to gratefully acknowledge the financial support of Diredawa University. The authors also grateful to Mr. Yonas Abera, and Mr. Besufikad Regassa for their valuable comments and suggestions to improve the quality of the paper.

\section{References}

[1] Reza, M. (2008) Price Transmission in Horticultural Products Markets Case Study of Date and Pistachio in Iran. International Conference on Applied Economics_ICOAE, Kastoria, 15-17 May 2008.

[2] USAID and Land O’Lakes, Inc (2010) Dairy Value Chains, End Markets and Food Security. The Next Stage in Dairy Development for Ethiopia.

[3] Tesfu, W. (2013) Asymmetric Price Transmission in the Slovak Liquid Milk Market. Journal of Agricultural Economics-Czech, 11, 512-514.

[4] Baghestany, A. and Sherafatmand, H. (2013) A Markov-Switching Vector Error Correction Model for Milk Market. International Journal of Agronomy and Plant Production, 4, 1782-1789.

[5] Barahona, J., Trejos, B., Lee, J., Chulaphan, W. and Jatuporn, C. (2013) Asymmetric Price Transmission in the Artisan Dairy Industry of Honduras. Asian Journal of Empirical Research, 3, 851-859.

[6] Octavio, F., Josef, B. and Jesus, C. (2010) Milking the Prices: The Role of Asymmetries in the Price Transmission 
Mechanism for Milk Products in Austria. Working Papers in Economics and Statistics, No. 2010-21.

[7] Katrakilidis, C. (2008) Testing for Market Integration and the Law of One Price: An Application to Selected European Milk Markets. International Journal of Economic Research, 5, 93-104.

[8] Rumankova, L. (2012) Examination of Market Structure in Selected Livestock Agri-Food Chains in the Czech Republic. Acta Universitatis Agriculturae et Silviculturae Mendelianae Brunensis, 60, 243-258. http://dx.doi.org/10.11118/actaun201260070243

[9] Bakucs, Z., Falkowski, J. and Ferto, I. (2012) Does Farm and Processing Industry Structure Matter for Price Transmission? Some Evidence from Transition Countries: A Comparison of Dairy Sectors in Hungary and Poland. Institute of Economics, Research Centre for Economic and Regional Studies, Hungarian Academy of Sciences.

[10] Chalajour, M. and Feizabadi, Y. (2013) Marketing Price Transmission Analysis in the Iranian Rice Market. African Journal of Agricultural Marketing, 1, 41-46.

[11] Asche, F., Jaffry, S. and Hartmann, J. (2005) Price Transmission and Market Integration: Vertical and Horizontal Price Linkages for Salmon. CEMARE Working Paper, No.1.

[12] Bor, O., Ismihan, M. and Bayaner, A. (2004) Asymmetry in Farm Price Transmission in the Turkish Fluid Milk Market. www.iamb.it/share/img_new_medit_articoli/975_02bor.pdf

[13] Verbeek, M. (2004) A Guide to Modern Econometrics. 2nd Edition, Erasmus University Rotterdam, John Wiley \& Sons Ltd., Hoboken.

[14] Johansen, S. and Juselius, K. (1990) Maximum Likelihood Estimation and Inference on Co-Integration-with Applications to the Demand for Money. Oxford Bulletin of Economics and Statistics, 52, 169-210. http://dx.doi.org/10.1111/j.1468-0084.1990.mp52002003.X

[15] Reziti I. and Panagopoulos, Y. (2008) Asymmetric Price Transmission in the Greek Agri-Food Sector: Some Tests. Agribusiness, 24, 16-30. http://dx.doi.org/10.1002/agr.20144 
Scientific Research Publishing (SCIRP) is one of the largest Open Access journal publishers. It is currently publishing more than 200 open access, online, peer-reviewed journals covering a wide range of academic disciplines. SCIRP serves the worldwide academic communities and contributes to the progress and application of science with its publication.

Other selected journals from SCIRP are listed as below. Submit your manuscript to us via either submit@scirp.org or Online Submission Portal.
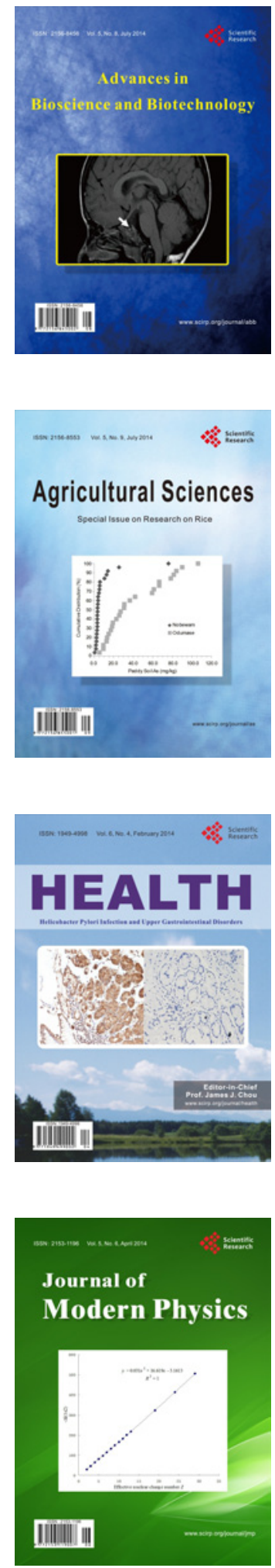
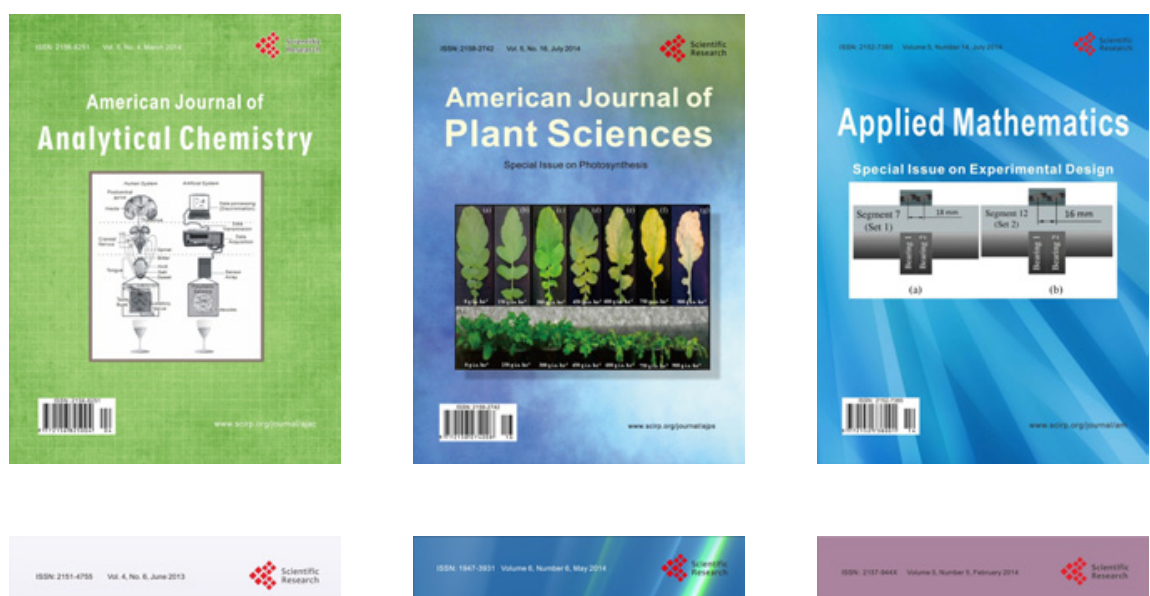

Creative Education
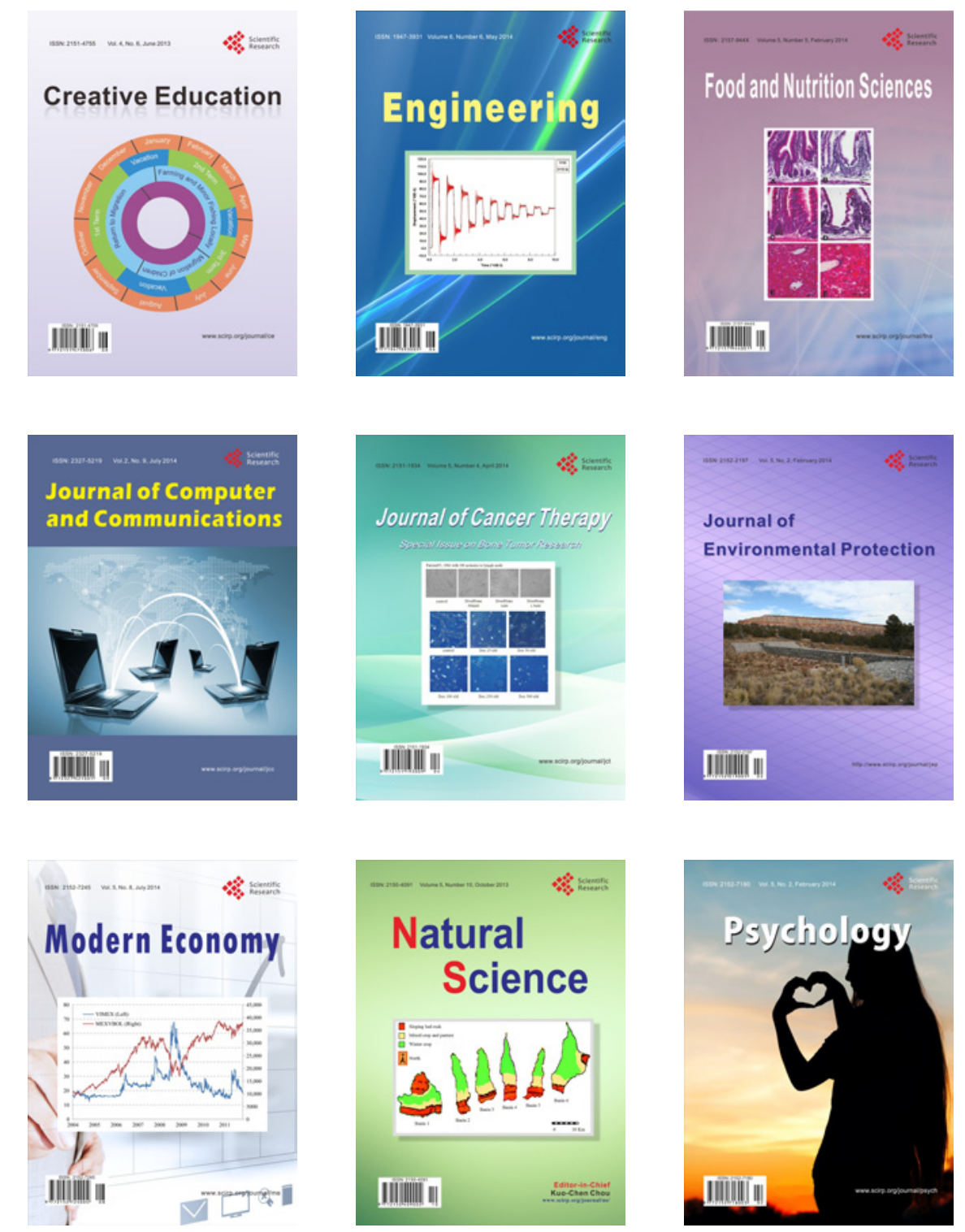